\title{
HAEMATOLOGICAL INVESTIGATIONS OF POPULATION SAMPLES IN JAMAICA
}

\author{
BY \\ W. E. MIALL, P. F. MILNER*, H. G. LOVELL, AND K. L. STANDARD \\ From the Medical Research Council Epidemiological Research Unit (Jamaica), and \\ the Department of Haematology*, University College Hospital, \\ University of the West Indies, Kingston 7, Jamaica
}

No large-scale studies of the prevalence of anaemia in the general populations of any of the West Indian territories have been reported previously. Interest in the medical characteristics of West Indian populations is increasing, both within the Caribbean area and in those countries where West Indian immigrants form an important section of the community, and in this paper we report the results of haematological investigations carried out as part of a series of surveys of cardiovascular disease in the adult population of Jamaica.

\section{Population Samples}

Two surveys were carried out in an inland rural district at Lawrence Tavern, where samples of adults aged 35 to 64 years were investigated in 1962-3 and 1963-4. A similar study was undertaken in 1965-6 in August Town, a suburban area close to the University of the West Indies. The ethnic origin of both populations is predominantly African.

Lawrence Tavern is the village centre of a rural area about 16 miles north of Kingston, the capital. It was selected as representative of many agricultural communities where the populations are made up almost entirely of small farmers and their families. The area lies between 750 and 1,500 feet above sea level and is an extremely hilly but fertile district, in which, however, the terrain is too steep and the plots of land are too small (mostly 1 to 5 acres), for agriculture to be efficient. Farming is done mainly by men, though women are active in the fields at planting and crop seasons. Mixed fruit and vegetable crops - bananas, plantain, coconut, cocoa, breadfruit, some citrus, and pulses, root crops, and sugar-are cultivated for home consumption and for sale in Kingston markets, but many people live at a subsistence level, particularly during the months between planting and harvesting. The population of about 7,500 people, living in an area of 12 square miles surrounding the village, was enumerated by a private census in 1962, and random samples of 200 adults of each sex in the three decades from 35 to 64 years were asked to attend a central clinic for cardiovascular investigations.
August Town, a suburban area near Kingston with a population of about 2,500 , was also enumerated by a private census and all adults aged 35 to 64 years were asked to attend the M.R.C. Epidemiological Research Unit for similar investigations. August Town is a comparatively flat district, lying at about 500 feet above sea level; it is poor by the standards of many Kingston suburbs but few people are destitute and living standards are slightly higher than in Lawrence Tavern. Occupations, as in most suburban populations in Jamaica, are varied but mostly lowly paid; probably a higher proportion of the women are gainfully employed in this area.

Table I (overleaf) shows the sample sizes and the response rates in the surveys.

\section{Methods AND TeChniques}

Blood specimens were obtained by venepuncture and divided between containers with either sequestrene or heparin as anticoagulant for the haematology and iron-free glass bottles for serum chemistry. They were refrigerated, transported to University College Hospital, and examined the same evening or the following day; the specimens obtained from each survey were examined in the same laboratory, using the same apparatus and technique on each occasion.

Haemoglobin was estimated by the cyanmethaemoglobin method against a commercial cyanmethaemoglobin standard in a Klett-Summerson photo-electric colorimeter. The packed cell volume (PCV) was measured in microcapillary tubes of even bore after centrifuging at 12,000 r.p.m. for 5 minutes. Serum iron and latent iron-building capacity were measured by the method of Beale, Bostrom, and Taylor (1961, 1962).

Haemoglobin electrophoresis was performed on each specimen after lysing with water and toluene, using a vertical paper method (Lehmann and Smith, 1954) and the Tris buffer system of Goldberg (1959). The haemoglobin $\mathrm{G}$ found is a $\beta$-chain abnormality known as haemoglobin $G$ Accra, described by Lehmann, Beale, and Boi-Doku (1964). Dr H. 
TABLE I

POPULATION SAMPLES INVESTIGATED FOR ANAEMIA JAMAICA, 1962-6

\begin{tabular}{|c|c|c|c|c|c|c|c|c|}
\hline \multirow{4}{*}{ Sex } & \multirow{4}{*}{ Age (yrs) } & \multicolumn{6}{|c|}{ Population } & \multirow{4}{*}{$\begin{array}{c}\text { Total } \\
\text { Investigated }\end{array}$} \\
\hline & & \multirow{3}{*}{ Sample } & \multicolumn{2}{|l|}{ Rural } & \multicolumn{3}{|c|}{ Suburban } & \\
\hline & & & \multicolumn{2}{|c|}{ Investigated } & \multirow{2}{*}{ Sample } & \multicolumn{2}{|c|}{ Investigated } & \\
\hline & & & No. & Per cent. & & No. & Per cent. & \\
\hline \multirow[t]{2}{*}{ Female } & $\begin{array}{l}35-44 \\
45-54 \\
55-64\end{array}$ & $\begin{array}{l}200 \\
200 \\
200\end{array}$ & $\begin{array}{l}167 \\
168 \\
173\end{array}$ & $\begin{array}{l}83 \cdot 5 \\
84 \cdot 0 \\
86 \cdot 5\end{array}$ & $\begin{array}{r}141 \\
105 \\
84\end{array}$ & $\begin{array}{r}122 \\
96 \\
72\end{array}$ & $\begin{array}{l}86 \cdot 5 \\
91 \cdot 4 \\
85 \cdot 7\end{array}$ & $\begin{array}{l}289 \\
264 \\
245\end{array}$ \\
\hline & Total & 600 & 508 & $84 \cdot 7$ & 330 & 290 & $87 \cdot 9$ & 798 \\
\hline \multirow[t]{2}{*}{ Male } & $\begin{array}{l}35-44 \\
45-54 \\
55-64\end{array}$ & $\begin{array}{l}200 \\
200 \\
200\end{array}$ & $\begin{array}{l}158 \\
175 \\
173\end{array}$ & $\begin{array}{l}79 \cdot 0 \\
87 \cdot 5 \\
86 \cdot 5\end{array}$ & $\begin{array}{r}118 \\
96 \\
53\end{array}$ & $\begin{array}{l}91 \\
75 \\
40\end{array}$ & $\begin{array}{l}77 \cdot 1 \\
78 \cdot 1 \\
75 \cdot 5\end{array}$ & $\begin{array}{l}249 \\
250 \\
213\end{array}$ \\
\hline & Total & 600 & 506 & $84 \cdot 3$ & 267 & 206 & $77 \cdot 2$ & 712 \\
\hline Both & Total & 1,200 & 1,014 & $84 \cdot 5$ & 597 & 496 & $83 \cdot 1$ & 1,510 \\
\hline
\end{tabular}

Lehmann very kindly examined this haemoglobin for us and identified the amino-acid substitution. Glucose-6-phosphate dehydrogenase activity was investigated by the dye test (Motulsky and CampbellKraut, 1961). ABO and Rhesus groups were tested in the first rural survey only and have been previously reported (Gibbs, 1963).

We have compared our findings with the results from haematological surveys carried out in the United Kingdom by Dr G. S. Kilpatrick and Dr P. C. Elwood, who kindly provided their data for this purpose. Their surveys were carried out in two Welsh mining valleys, the Rhondda Fach (Kilpatrick and Hardisty, 1961) and the Rhondda Fawr (Wood and Elwood, 1966), in Belfast, Northern Ireland (Elwood, 1964), and in an agricultural community in Wensleydale, Yorkshire (Kilpatrick, 1961). In
Kilpatrick's surveys haemoglobin was estimated as î oxyhaemoglobin in an E.E.L. colorimeter; Wood or and Elwood used the cyanmethaemoglobin tech-은 nique with an E.E.L. colorimeter. PCV was determined after centrifuging in a Hawksley micro- $\rightarrow$ haematocrit for 5 minutes. Serum iron levels were measured (in Kilpatrick's surveys only) by Jordan's $\vec{\varphi}$ modification of Ramsay's method (Jordan, 1956). 8 .

\section{RESULTS}

(1) Haemoglobin, PCV, and MCHC

\section{DisTRIBUTIONS}

Mean values and standard deviations for haemoglobin, PCV, and mean corpuscular haemoglobin concentrations (MCHC) are shown for Jamaican females in Table II, which also includes results from surveys in the United Kingdom.

TABLE II

HAEMATOLOGICAL INDICES IN JAMAICAN AND UNITED KINGDOM FEMALE POPULATIONS

\begin{tabular}{|c|c|c|c|c|c|c|c|c|c|}
\hline \multicolumn{3}{|c|}{ Population } & \multirow{2}{*}{$\begin{array}{l}\text { No. } \\
\text { Tested }\end{array}$} & \multicolumn{2}{|c|}{$\begin{array}{l}\text { Haemoglobin } \\
(\mathrm{g} . / 100 \mathrm{ml} .)\end{array}$} & \multicolumn{2}{|c|}{ PCV } & \multicolumn{2}{|c|}{$\mathrm{MCHC}$} \\
\hline \multicolumn{2}{|c|}{ Area } & Age (yrs) & & Mean & S.D. & Mean & S.D. & Mean & S.D. \\
\hline \multirow{2}{*}{ Jamaica } & $\begin{array}{l}\text { (1) } \\
\text { Rural }\end{array}$ & $\begin{array}{l}35-44 \\
45-54 \\
55-64\end{array}$ & $\begin{array}{l}167 \\
168 \\
173\end{array}$ & $\begin{array}{l}12 \cdot 5 \\
12 \cdot 5 \\
12 \cdot 6\end{array}$ & $\begin{array}{l}1 \cdot 2 \\
1.6 \\
1 \cdot 4\end{array}$ & $\begin{array}{l}38 \cdot 5 \\
38 \cdot 9 \\
39 \cdot 2\end{array}$ & $\begin{array}{l}3 \cdot 1 \\
3 \cdot 8 \\
3 \cdot 6\end{array}$ & $\begin{array}{l}32 \cdot 0 \\
31 \cdot 8 \\
31 \cdot 7\end{array}$ & $\begin{array}{l}1 \cdot 8 \\
1 \cdot 8 \\
1 \cdot 9\end{array}$ \\
\hline & $\begin{array}{c}\text { (2) } \\
\text { Suburban }\end{array}$ & $\begin{array}{l}35-44 \\
45-54 \\
55-64\end{array}$ & $\begin{array}{r}122 \\
96 \\
72\end{array}$ & $\begin{array}{l}12 \cdot 4 \\
12 \cdot 6 \\
12 \cdot 7\end{array}$ & $\begin{array}{l}1 \cdot 4 \\
1 \cdot 4 \\
1 \cdot 2\end{array}$ & $\begin{array}{l}39 \cdot 2 \\
39 \cdot 8 \\
40 \cdot 2\end{array}$ & $\begin{array}{l}3 \cdot 8 \\
3 \cdot 4 \\
3 \cdot 1\end{array}$ & $\begin{array}{l}31 \cdot 7 \\
31 \cdot 7 \\
31 \cdot 6\end{array}$ & $\begin{array}{l}1 \cdot 9 \\
1 \cdot 7 \\
2 \cdot 1\end{array}$ \\
\hline \multirow{2}{*}{$\begin{array}{c}\text { United } \\
\text { Kingdom }\end{array}$} & $\begin{array}{l}\text { (3) } \\
\text { Rural }\end{array}$ & $\begin{array}{l}35-44 \\
45-54 \\
55-64\end{array}$ & $\begin{array}{l}52 \\
42 \\
38\end{array}$ & $\begin{array}{l}12 \cdot 7 \\
13 \cdot 1 \\
13 \cdot 0\end{array}$ & $\begin{array}{l}1 \cdot 3 \\
1 \cdot 0 \\
1 \cdot 1\end{array}$ & $\begin{array}{l}40 \cdot 9 \\
42 \cdot 1 \\
41 \cdot 7\end{array}$ & $\begin{array}{l}3 \cdot 5 \\
3 \cdot 4 \\
3 \cdot 6\end{array}$ & $\begin{array}{l}31 \cdot 0 \\
31 \cdot 1 \\
31 \cdot 3\end{array}$ & $\begin{array}{l}1 \cdot 4 \\
1 \cdot 2 \\
1 \cdot 2\end{array}$ \\
\hline & $\begin{array}{c}\text { (4) } \\
\text { Urban }\end{array}$ & $\begin{array}{r}34-44 \\
45-54 \\
55-64\end{array}$ & $\left\{\begin{array}{r}28 \\
37 \\
37 \\
180\end{array}\right.$ & $\begin{array}{l}12 \cdot 1 \\
13 \cdot 3 \\
13 \cdot 8 \\
13 \cdot 3\end{array}$ & $\begin{array}{l}1 \cdot 7 \\
1 \cdot 5 \\
1 \cdot 1 \\
1 \cdot 7\end{array}$ & $\begin{array}{l}38 \cdot 1 \\
40 \cdot 6 \\
41 \cdot 7 \\
41 \cdot 7\end{array}$ & $\begin{array}{l}3 \cdot 2 \\
3 \cdot 3 \\
3 \cdot 4 \\
4 \cdot 3\end{array}$ & $\begin{array}{l}31 \cdot 5 \\
31 \cdot 3 \\
33 \cdot 0 \\
31 \cdot 7\end{array}$ & $\begin{array}{l}2 \cdot 6 \\
1 \cdot 5 \\
1 \cdot 5 \\
1 \cdot 7\end{array}$ \\
\hline
\end{tabular}

(1) Lawrence Tavern, St. Andrew, Jamaica.

(2) August Town, St. Andrew, Jamaica.

(3) Wensleydale, Yorkshire, England.
(4) Rhondda Fawr, Glamorgan, Wales.

(5) Rhondda Fach, Glamorgan, Wales (55-64 yr group only). 


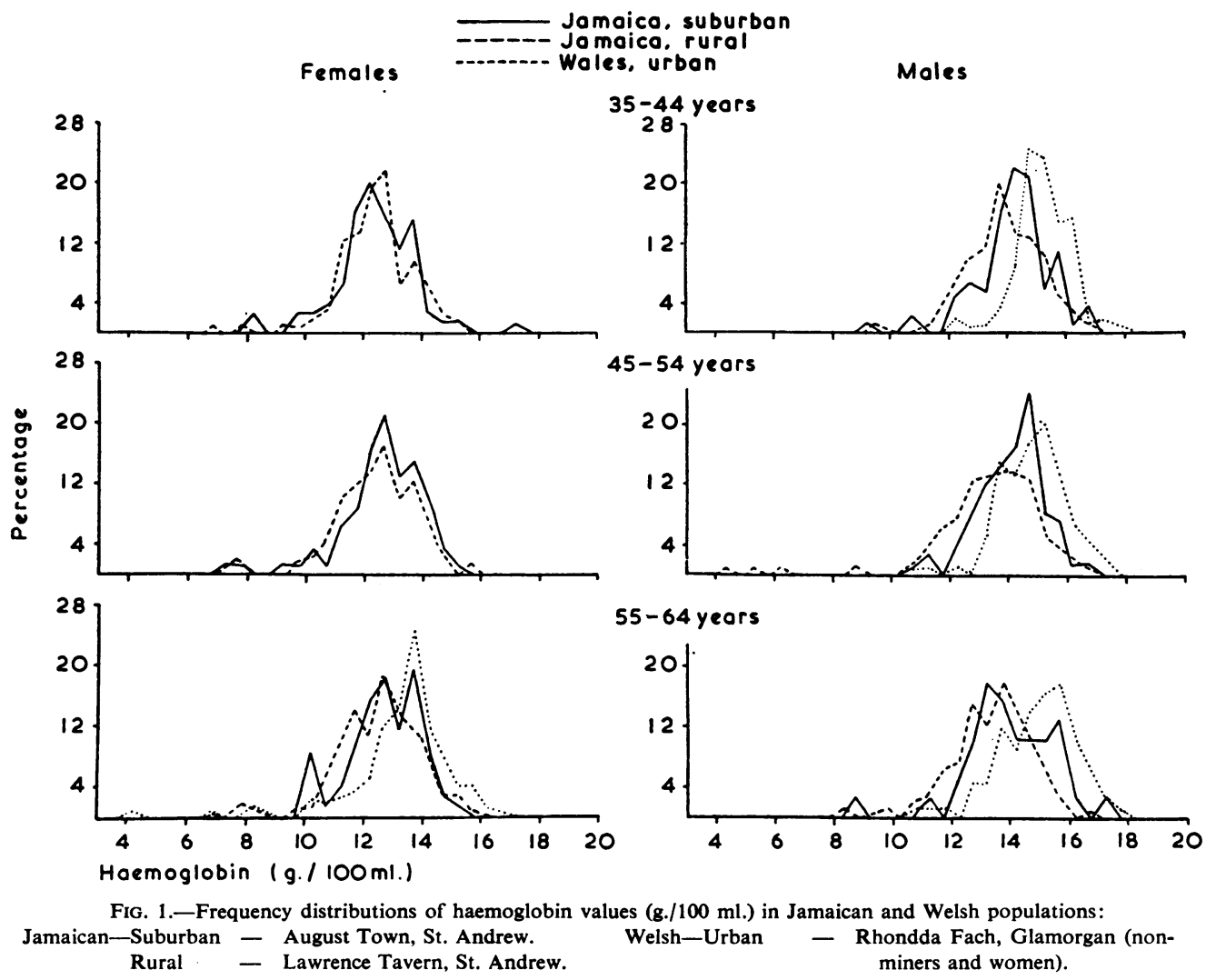

The mean haemoglobin values and their distributions were similar in the Jamaican female populations. Mean levels (Table II, Fig. 1) in the three age groups varied between 12.4 and $12.7 \mathrm{~g} . / 100 \mathrm{ml}$., and showed only a slight tendency to increase with age when losses due to menstruation and childbearing diminish. Figures for the United Kingdom showed a greater rise with age, and though about the same for the 35 to 44-year age group, were about $0.5 \mathrm{~g}$. higher in the older women.

PCV averaged from 38.5 to 40.2 in the female populations (Fig. 2, overleaf), showing a small but consistent increase with age, and were a little lower than in the United Kingdom. Mean MCHC values varied only between $31 \cdot 6$ and $32 \cdot 0$, tended to fall fractionally with increasing age, but were otherwise closely similar to United Kingdom values.

For males (Table III, overleaf), a consistent difference was found between the rural and suburban subjects in haemoglobin levels and in PCV (Figs 1 and 2).
Mean haemoglobin values in the rural men varied between 13.9 and $13.3 \mathrm{~g} . / 100 \mathrm{ml}$. compared with 14.2 and $14.0 \mathrm{~g} . / 100 \mathrm{ml}$. in the suburban group. PCV measurements confirmed the difference; MCHC values were again very similar. United Kingdom haemoglobin levels were also higher for urban than for rural men; United Kingdom urban values averaged about $0.8 \mathrm{~g}$. higher than the suburban Jamaicans and over $1.3 \mathrm{~g}$. higher than the rural Jamaicans. United Kingdom rural mean values were similar to those for the suburban males in Jamaica and about $0.5 \mathrm{~g}$. higher than those for rural males in Jamaica. PCV were also higher in the United Kingdom (Fig. 2), so that MCHC values showed only small differences. In Jamaica, as in the United Kingdom; haemoglobin levels tend to fall slightly in males with increasing age.

\section{(2) The Prevalence of Anaemia}

Anaemia was defined for purposes of referral as less than $11 \mathrm{~g} . / 100 \mathrm{ml}$. for women and less than 
TABLE III

HAEMATOLOGICAL INDICES IN JAMAICAN AND UNITED KINGDOM MALE POPULATIONS

\begin{tabular}{|c|c|c|c|c|c|c|c|c|c|c|}
\hline \multicolumn{4}{|c|}{ Population } & \multirow{2}{*}{$\begin{array}{l}\text { No. } \\
\text { Tested }\end{array}$} & \multicolumn{2}{|c|}{$\begin{array}{c}\text { Haemoglobin } \\
\text { (g./100 ml.) }\end{array}$} & \multicolumn{2}{|c|}{ PCV } & \multicolumn{2}{|c|}{$\mathrm{MCHC}$} \\
\hline \multicolumn{2}{|c|}{ Area } & & Age (yrs) & & Mean & S.D. & Mean & S.D. & Mean & S.D. \\
\hline \multirow{2}{*}{ Jamaica } & $\stackrel{\text { (1) }}{\text { Rural }}$ & & $\begin{array}{l}35-44 \\
45-54 \\
55-64\end{array}$ & $\begin{array}{l}158 \\
175 \\
173\end{array}$ & $\begin{array}{l}13 \cdot 9 \\
13 \cdot 4 \\
13 \cdot 4\end{array}$ & $\begin{array}{l}1 \cdot 3 \\
1 \cdot 8 \\
1 \cdot 4\end{array}$ & $\begin{array}{l}42 \cdot 6 \\
41 \cdot 8 \\
41 \cdot 8\end{array}$ & $\begin{array}{l}3 \cdot 3 \\
4 \cdot 6 \\
3 \cdot 7\end{array}$ & $\begin{array}{l}32 \cdot 3 \\
31 \cdot 7 \\
31 \cdot 9\end{array}$ & $\begin{array}{l}1 \cdot 6 \\
1 \cdot 8 \\
1 \cdot 7\end{array}$ \\
\hline & $\begin{array}{c}\text { (2) } \\
\text { Suburban }\end{array}$ & & $\begin{array}{l}35-44 \\
45-54 \\
55-64\end{array}$ & $\begin{array}{l}91 \\
75 \\
40\end{array}$ & $\begin{array}{l}14 \cdot 2 \\
14 \cdot 1 \\
14 \cdot 0\end{array}$ & $\begin{array}{l}1 \cdot 3 \\
1 \cdot 2 \\
1 \cdot 5\end{array}$ & $\begin{array}{l}43 \cdot 5 \\
43 \cdot 6 \\
42 \cdot 4\end{array}$ & $\begin{array}{l}3 \cdot 3 \\
2 \cdot 9 \\
3 \cdot 7\end{array}$ & $\begin{array}{l}32 \cdot 1 \\
31 \cdot 8 \\
32 \cdot 4\end{array}$ & $\begin{array}{l}1 \cdot 6 \\
1 \cdot 8 \\
1 \cdot 9\end{array}$ \\
\hline \multirow{3}{*}{$\begin{array}{l}\text { United } \\
\text { Kingdom }\end{array}$} & $\begin{array}{l}(3) \\
\text { Rural }\end{array}$ & & $\begin{array}{l}35-44 \\
45-54 \\
55-64\end{array}$ & $\begin{array}{l}34 \\
36 \\
25 \\
\end{array}$ & $\begin{array}{l}14 \cdot 3 \\
14 \cdot 1 \\
13 \cdot 9\end{array}$ & $\begin{array}{l}0 \cdot 9 \\
1 \cdot 1 \\
1 \cdot 2\end{array}$ & $\begin{array}{l}45 \cdot 0 \\
44 \cdot 8 \\
45 \cdot 1\end{array}$ & $\begin{array}{l}2 \cdot 6 \\
3 \cdot 9 \\
3 \cdot 7\end{array}$ & $\begin{array}{l}31 \cdot 8 \\
31 \cdot 6 \\
30 \cdot 8\end{array}$ & $\begin{array}{l}1 \cdot 3 \\
2 \cdot 3 \\
1 \cdot 1\end{array}$ \\
\hline & \multirow{2}{*}{ Urban } & $\begin{array}{l}\text { Non- } \\
\text { miners } \\
(4)\end{array}$ & $\begin{array}{l}35-44 \\
45-54 \\
55-64\end{array}$ & $\begin{array}{l}85 \\
89 \\
91 \\
\end{array}$ & $\begin{array}{l}15 \cdot 2 \\
14 \cdot 8 \\
14 \cdot 9\end{array}$ & $\begin{array}{l}1 \cdot 0 \\
1 \cdot 2 \\
1 \cdot 3\end{array}$ & $\begin{array}{l}45 \cdot 7 \\
45 \cdot 1 \\
46 \cdot 0\end{array}$ & $\begin{array}{l}3 \cdot 0 \\
3 \cdot 6 \\
3 \cdot 7\end{array}$ & $\begin{array}{l}33 \cdot 0 \\
32 \cdot 6 \\
32 \cdot 2\end{array}$ & $\begin{array}{l}1 \cdot 2 \\
1 \cdot 4 \\
1 \cdot 4\end{array}$ \\
\hline & & $\begin{array}{l}\text { Miners } \\
\text { and } \\
\text { ex-miners } \\
\text { (5) }\end{array}$ & $\begin{array}{l}35-44 \\
45-54 \\
55-64\end{array}$ & $\begin{array}{l}90 \\
95 \\
93\end{array}$ & $\begin{array}{l}14 \cdot 9 \\
15 \cdot 0 \\
14 \cdot 6\end{array}$ & $\begin{array}{l}1 \cdot 0 \\
1 \cdot 1 \\
1 \cdot 2\end{array}$ & $\begin{array}{l}45 \cdot 6 \\
45 \cdot 9 \\
45 \cdot 3\end{array}$ & $\begin{array}{l}3 \cdot 0 \\
3 \cdot 1 \\
3 \cdot 6\end{array}$ & $\begin{array}{l}32 \cdot 5 \\
32 \cdot 4 \\
32 \cdot 1\end{array}$ & $\begin{array}{l}1 \cdot 4 \\
1 \cdot 2 \\
1 \cdot 2\end{array}$ \\
\hline
\end{tabular}

(1) Lawrence Tavern, St. Andrew, Jamaica.

(2) August Town, St. Andrew, Jamaica.

(3) Wensleydale, Yorkshire, England.
(4) Rhondda Fach, Glamorgan, Wales (Non-miners).

(5) Rhondda Fach, Glamorgan, Wales (Miners and ex-miners).
Females $\quad$ Jamaica, suburban -.... Woles, urban

$35-44$ years
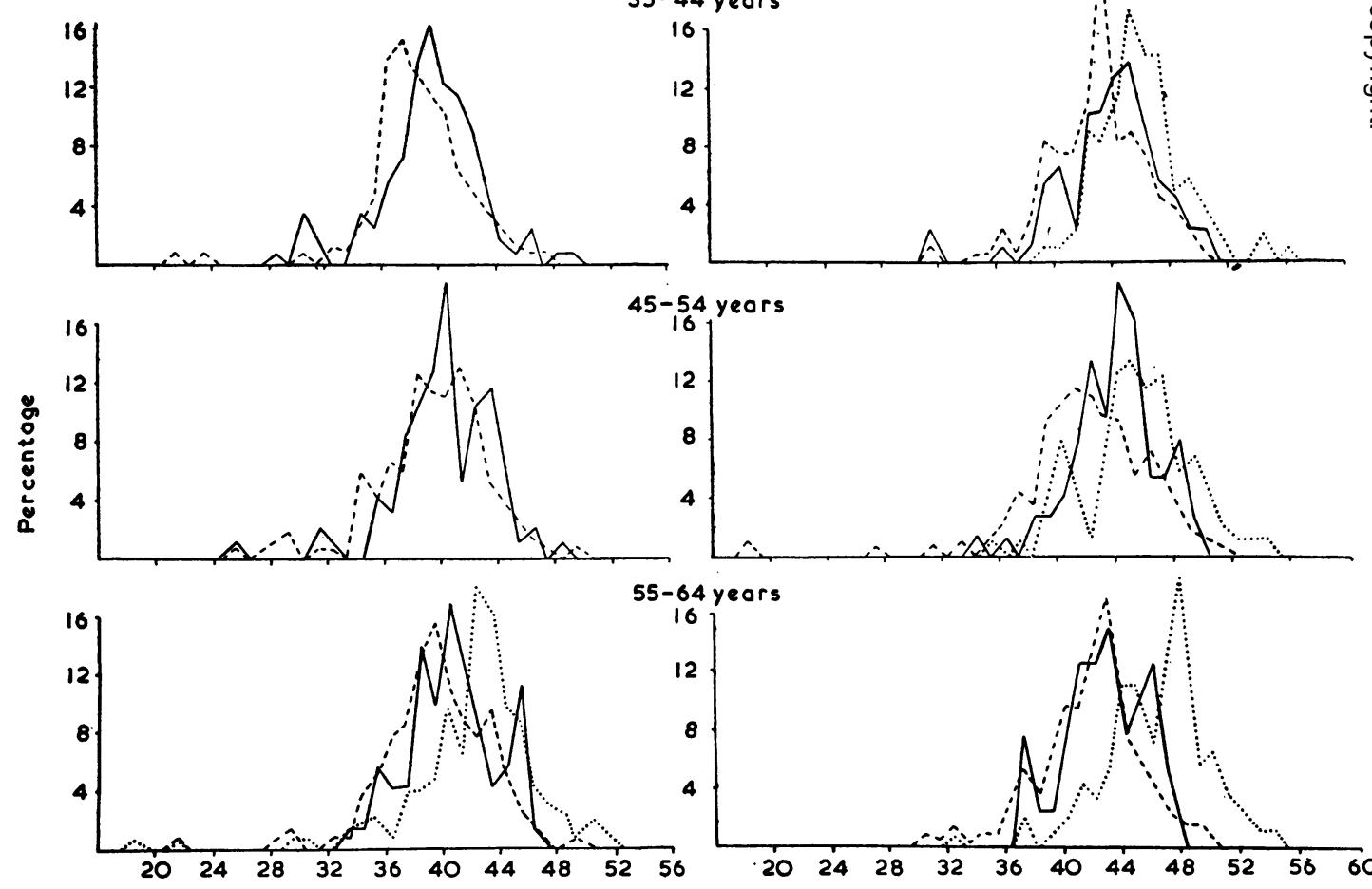

Packed cell volume

FIG. 2.-Frequency distributions of packed cell volumes in Jamaican and Welsh populations:

Rural - Lawrence, Tavern, St. Andrew.
Moles
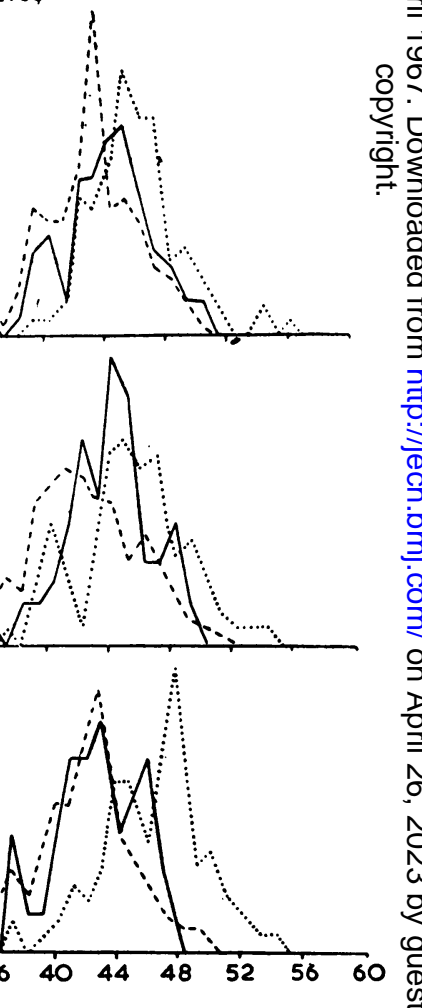

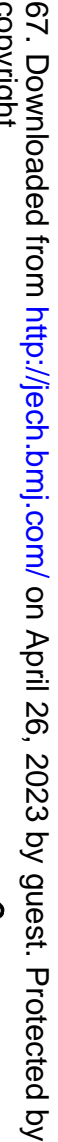


$12 \mathrm{~g} . / 100 \mathrm{ml}$. for men. Using these criteria the prevalence rates found in the Jamaican populations are compared with those for the United Kingdom samples in Table IV. Age-specific rates show some differences in the female populations; in the Jamaican rural area the prevalence was highest in the 45 to 54-year age group, whereas in all the other surveys anaemia was found more commonly in the younger and older women, with somewhat lower rates in the 45 to 54-year age group. The "equivalent average rates" (i.e. means of the three age-specific rates) for the two Jamaican female populations were 9.5 and 9.6 per cent. in the rural and urban areas respectively; they were intermediate between the United Kingdom rural and urban groups which were $6 \cdot 3$ and 11.5 per cent. respectively.

Males in the Jamaican rural population showed a considerably higher "equivalent average rate" of anaemia (11.9 per cent.) than those in the suburban area $(4 \cdot 1$ per cent.), where it was of the same order as that found in the rural sample from the United Kingdom ( 4.6 per cent.); anaemia was less common in the United Kingdom urban group ( $1 \cdot 7$ per cent.). In men the prevalence of anaemia increased with age.

The types of anaemia found are shown in Table V; anaemia was considered hypochromic when the $\mathrm{MCHC}$ was less than 31 , borderline when it was 31 , and normochromic when 32 or more.

\section{(3) Serum Iron and Latent Binding Capacity}

Serum iron was measured for 297 of the 526 subjects who were examined in the first rural survey. The tests were done without knowledge of the other haematological results. Total iron binding capacity was calculated from the addition of the serum iron value and the latent binding capacity and the percentage saturation derived. Hamilton, Gubler, Cartwright, and Wintrobe (1950) found that serum iron levels were higher in the morning than in the

TABLE IV

PREVALENCE OF ANAEMIA* FOUND IN POPULATION STUDIES, JAMAICA AND UNITED KINGDOM

\begin{tabular}{|c|c|c|c|c|c|c|c|c|c|c|c|c|c|c|c|}
\hline \multirow{2}{*}{\multicolumn{2}{|c|}{ Population Sample }} & \multirow{2}{*}{. } & \multirow{2}{*}{$\cdots$} & \multicolumn{6}{|c|}{ Jamaica } & \multicolumn{6}{|c|}{ United Kingdom } \\
\hline & & & & \multicolumn{3}{|c|}{ Rural } & \multicolumn{3}{|c|}{ Suburban } & \multicolumn{3}{|c|}{ Rural } & \multicolumn{3}{|c|}{ Urbant } \\
\hline \multirow[b]{2}{*}{ Sex } & \multirow{2}{*}{\multicolumn{3}{|c|}{ Age (yrs) }} & \multirow{2}{*}{$\begin{array}{l}\text { No. } \\
\text { investi- } \\
\text { gated }\end{array}$} & \multicolumn{2}{|c|}{ Anaemic } & \multirow{2}{*}{$\begin{array}{c}\text { No. } \\
\text { investi- } \\
\text { gated }\end{array}$} & \multicolumn{2}{|c|}{ Anaemic } & \multirow{2}{*}{$\begin{array}{c}\text { No. } \\
\text { investi- } \\
\text { gated }\end{array}$} & \multicolumn{2}{|c|}{ Anaemic } & \multirow{2}{*}{$\begin{array}{l}\text { No. } \\
\text { investi- } \\
\text { gated }\end{array}$} & \multicolumn{2}{|c|}{ Anaemic } \\
\hline & & & & & No. & $\begin{array}{l}\text { Per } \\
\text { cent. }\end{array}$ & & No. & $\begin{array}{c}\text { Per } \\
\text { cent. }\end{array}$ & & No. & $\begin{array}{c}\text { Per } \\
\text { cent. }\end{array}$ & & No. & $\begin{array}{l}\text { Per } \\
\text { cent. }\end{array}$ \\
\hline Female & $\begin{array}{c}\text { Equiva } \\
\text { aver }\end{array}$ & $\begin{array}{l}35-44 \\
45-54 \\
55-64 \\
\text { lent } \\
\text { age rate }\end{array}$ & . & $\begin{array}{l}167 \\
168 \\
173\end{array}$ & $\begin{array}{l}11 \\
22 \\
15\end{array}$ & $\begin{array}{r}6 \cdot 6 \\
13 \cdot 1 \\
8 \cdot 7 \\
9 \cdot 5\end{array}$ & $\begin{array}{r}122 \\
96 \\
72\end{array}$ & $\begin{array}{r}13 \\
8 \\
67\end{array}$ & $\begin{array}{r}10 \cdot 7 \\
8 \cdot 3 \\
9 \cdot 7 \\
9 \cdot 6\end{array}$ & $\begin{array}{l}45 \\
34 \\
32\end{array}$ & $\begin{array}{l}3 \\
1 \\
3\end{array}$ & $\begin{array}{l}6 \cdot 7 \\
2 \cdot 9 \\
9 \cdot 4 \\
6 \cdot 3\end{array}$ & $\begin{array}{r}69 \\
82 \\
244\end{array}$ & $\begin{array}{r}11 \\
7 \\
25\end{array}$ & $\begin{array}{r}15 \cdot 9 \\
8 \cdot 5 \\
10 \cdot 2 \\
11 \cdot 5\end{array}$ \\
\hline Male & $\begin{array}{c}\text { Equiva } \\
\text { aver: }\end{array}$ & $\begin{array}{l}35-44 \\
45-54 \\
55-64 \\
\text { lent } \\
\text { age rate }\end{array}$ & .. & $\begin{array}{l}158 \\
175 \\
173\end{array}$ & $\begin{array}{l}10 \\
26 \\
25\end{array}$ & $\begin{array}{r}6 \cdot 3 \\
14 \cdot 9 \\
14 \cdot 5 \\
11 \cdot 9\end{array}$ & $\begin{array}{l}91 \\
75 \\
40\end{array}$ & $\begin{array}{l}3 \\
3 \\
2\end{array}$ & $\begin{array}{l}3 \cdot 3 \\
4 \cdot 0 \\
5 \cdot 0 \\
4 \cdot 1\end{array}$ & $\begin{array}{l}34 \\
36 \\
25\end{array}$ & $\begin{array}{l}1 \\
1 \\
2\end{array}$ & $\begin{array}{l}2 \cdot 9 \\
2 \cdot 8 \\
8 \cdot 0 \\
4 \cdot 6\end{array}$ & $\begin{array}{l}175 \\
184 \\
184\end{array}$ & $\begin{array}{l}1 \\
2 \\
6\end{array}$ & $\begin{array}{l}0.6 \\
1.1 \\
3 \cdot 3 \\
1 \cdot 7\end{array}$ \\
\hline
\end{tabular}

* Anaemia-less than $11 \mathrm{~g} . / 100 \mathrm{ml}$. for females, less than $12 \mathrm{~g} . / 100 \mathrm{ml}$. for males.

† For females pooled data from surveys in Belfast, N. Ireland. Rhondda Fawr, and Rhondda Fach.

For males, data from Rhondda Fach (miners and non-miners).

TABLE V

TYPE OF ANAEMIA FOUND IN POPULATION STUDIES, JAMAICA AND UNITED KINGDOM

\begin{tabular}{|c|c|c|c|c|c|c|c|c|c|}
\hline \multicolumn{3}{|c|}{ Population Sample } & \multirow{2}{*}{$\begin{array}{c}\text { No. } \\
\text { Investigated }\end{array}$} & \multicolumn{2}{|c|}{ Anaemia* } & \multicolumn{4}{|c|}{ Type of Anaemia } \\
\hline Sex & \multicolumn{2}{|c|}{ Area } & & No. & $\begin{array}{l}\text { Per } \\
\text { cent. }\end{array}$ & $\begin{array}{l}\text { Hypochromic } \\
(\mathrm{MCHC}<31)\end{array}$ & $\begin{array}{l}\text { Borderline } \\
\text { (MCHC 31) }\end{array}$ & $\begin{array}{l}\text { Normochromic } \\
(\mathrm{MCHC}>31)\end{array}$ & $\begin{array}{c}\text { Not known } \\
\text { (MCHC not done) }\end{array}$ \\
\hline \multirow{2}{*}{ Female } & Jamaica & $\begin{array}{c}\text { Rural } \\
\text { Suburban }\end{array}$ & $\begin{array}{l}508 \\
290\end{array}$ & $\begin{array}{l}48 \\
28\end{array}$ & $\begin{array}{l}9 \cdot 4 \\
9 \cdot 7\end{array}$ & $\begin{array}{l}28 \\
20\end{array}$ & $\begin{array}{r}10 \\
3\end{array}$ & $\begin{array}{r}10 \\
4\end{array}$ & $\overline{1}$ \\
\hline & $\begin{array}{c}\text { United } \\
\text { Kingdom }\end{array}$ & $\begin{array}{l}\text { Rural } \\
\text { Urban }\end{array}$ & $\begin{array}{l}132 \\
180 \dagger\end{array}$ & $\begin{array}{r}7 \\
14\end{array}$ & $\begin{array}{l}5 \cdot 3 \\
7 \cdot 8\end{array}$ & $\begin{array}{r}6 \\
10\end{array}$ & $\overline{3}$ & 1 & 二 \\
\hline \multirow{2}{*}{ Male } & Jamaica & $\begin{array}{c}\text { Rural } \\
\text { Suburban }\end{array}$ & $\begin{array}{l}506 \\
206\end{array}$ & $\begin{array}{r}61 \\
8\end{array}$ & $\begin{array}{r}12 \cdot 1 \\
3 \cdot 9\end{array}$ & $\begin{array}{r}36 \\
6\end{array}$ & 10 & $\begin{array}{r}14 \\
2\end{array}$ & 1 \\
\hline & $\begin{array}{c}\text { United } \\
\text { Kingdom }\end{array}$ & $\begin{array}{l}\text { Rural } \\
\text { Urban }\end{array}$ & $\begin{array}{r}95 \\
543\end{array}$ & $\begin{array}{l}4 \\
9\end{array}$ & $\begin{array}{l}4 \cdot 2 \\
1.7\end{array}$ & $\begin{array}{l}3 \\
4\end{array}$ & $\overline{3}$ & $\begin{array}{l}1 \\
2\end{array}$ & 二 \\
\hline
\end{tabular}

* Anaemia defined as $<11 \mathrm{~g} . / 100 \mathrm{ml}$. for females. $<12 \mathrm{~g} / 100 \mathrm{ml}$. for males.

† Rhondda Fach, Glamorgan, Wales (subjects all aged 55-64 yrs). 
evening by as much as 57 per cent., and diurnal fluctuations of this order have been found by other workers. By the method used, Beale, Bostrom, and Taylor (1962) found an average morning serum iron level of $116 \mu \mathrm{g} . / 100 \mathrm{ml}$. for adult males (range 51-173) and $107 \mu \mathrm{g} . / 100 \mathrm{ml}$. for adult females (range 46-168).

The majority of our blood samples were drawn in the morning but some were taken in the early afternoon. Mean serum iron values for age and sex are shown in Table VI. The mean value for men was $90 \mu \mathrm{g} . / 100 \mathrm{ml}$. and for women $80 \mu \mathrm{g} . / 100 \mathrm{ml}$. Among the subjects fully investigated in the rural area in the first survey, twelve out of 118 men and sixteen out of 127 women had serum iron levels below $50 \mu \mathrm{g} . / 100 \mathrm{ml}$. and in all of these cases the saturation of transferrin was below 17 per cent. This is probably the best index of the prevalence of iron deficiency in the group as a whole; the normal range of iron saturation of transferrin is $25-35$ per cent., levels below 17 per cent. being usually associated with other laboratory evidence of iron deficiency but not necessarily with clinical anaemia. In another fifteen men and 26 women in the rural area, the saturation was below 20 per cent. without evidence of anaemia and these probably constitute a group with latent iron deficiency (Bainton and Finch, 1964).

TABLE VI

MEAN SERUM IRON LEVELS $(\mu \mathrm{g} . / 100 \mathrm{ml}$.) IN JAMAICAN RURAL SUBJECTS

\begin{tabular}{c|c|cc|c|c|c}
\hline \multirow{2}{*}{ Age (yrs) } & \multicolumn{3}{|c|}{ Females } & \multicolumn{3}{|c}{ Males } \\
\cline { 2 - 5 } & No. & Mean & S.D. & No. & Mean & S.D. \\
\hline $35-44$ & 48 & $79 \cdot 0$ & $30 \cdot 3$ & 50 & $93 \cdot 8$ & $34 \cdot 3$ \\
$45-54$ & 48 & $81 \cdot 7$ & $35 \cdot 5$ & 40 & $90 \cdot 8$ & $35 \cdot 2$ \\
$55-64$ & 60 & $78 \cdot 2$ & $26 \cdot 0$ & 51 & $85 \cdot 0$ & $28 \cdot 8$ \\
\hline All Ages & 156 & $79 \cdot 5$ & $30 \cdot 3$ & 141 & $89 \cdot 8$ & $32 \cdot 7$ \\
\hline
\end{tabular}

The serum iron values are low compared with those found in the United Kingdom. In the Rhondda Fach, Kilpatrick and Hardisty (1961) found mean values in men aged $35-64$ years of $118.4 \mu \mathrm{g} . / 100 \mathrm{ml}$. for miners and ex-miners, $123.3 \mu \mathrm{g} . / 100 \mathrm{ml}$. for non-miners, and $103.8 \mu \mathrm{g} . / 100 \mathrm{ml}$. for women aged 55-64 years.

The lower figures for the Jamaican men $(90 \mu \mathrm{g} . /$ $100 \mathrm{ml}$.) and women $(80 \mu \mathrm{g} . / 100 \mathrm{ml}$.) may be partially explained by differences in laboratory methods. However, Milner (1965) found a mean level of $100 \mu \mathrm{g} . / \mathrm{ml}$. in 74 university students, with a range of 57 to $150 \mu \mathrm{g} . / 100 \mathrm{ml}$. and only slight differences between the sexes. All these persons had normal haemoglobin levels and transferrin saturations above 20 per cent. The lower mean levels in the survey population, which covers an older age group and includes multiparous women, probably represent a true difference from those of wellnourished university students.

\section{(4) ABO and Rhesus Blood Groups}

The results of testing 507 specimens from the first rural survey with anti-A and anti-B serum, and of 504 tests with anti-D serum have been described by Gibbs (1963). $55 \cdot 8$ per cent. were of Blood Group O, 19.9 per cent. were of Group A, $21 \cdot 5$ per cent. of Group B, and only 2.8 per cent. of Group AB. Rhesus (D) negative subjects formed only 2.6 per cent. of the group tested.

\section{(5) Glucose-6-Phosphate Dehydrogenase DEFICIENCY}

Qualitative tests for deficiency of the glucose-6- i phosphate dehydrogenase enzyme were done for of subjects in the second rural survey only, and were $\mathrm{O}$ considered positive when the decolorization of brilliant cresyl blue was not completed within $2 \stackrel{2}{2}$ hours in tubes incubated at $37^{\circ} \mathrm{C}$.

G-6-P D deficiency was found in $4 \cdot 1$ per cent. of $\vec{\bullet}$ the women and in 13.5 per cent. of men (Table VII); 37 ( $9 \cdot 2$ per cent.) of 404 subjects with haemo globin AA, four $(6 \cdot 1$ per cent.) of 66 with the sicke cell trait, one $(8 \cdot 3$ per cent.) of twelve with haemoglobin AC, and two of the six with AG haemoglobin were deficient in the enzyme; the differences are not significant with these small numbers.

\section{TABLE VII}

RESULTS OF TESTS FOR GLUCOSE-6-PHOSPHATE DEHYDROGENASE IN A RURAL POPULATION (LAWRENCE TAVERN) IN JAMAICA, 1963

\begin{tabular}{|c|c|c|c|c|c|}
\hline \multicolumn{2}{|c|}{ Population Sample } & \multirow{2}{*}{$\begin{array}{l}\text { No. in } \\
\text { Survey }\end{array}$} & \multirow{2}{*}{$\begin{array}{l}\text { No. } \\
\text { Investi- } \\
\text { gated for } \\
\text { G-6-P D }\end{array}$} & \multicolumn{2}{|c|}{ G-6-P D Deficiency } \\
\hline Sex & Age (yrs) & & & No. & Per cent. \\
\hline \multirow[t]{2}{*}{ Female } & $\begin{array}{l}35-44 \\
45-54 \\
55-64\end{array}$ & $\begin{array}{l}85 \\
90 \\
86\end{array}$ & $\begin{array}{l}81 \\
81 \\
83\end{array}$ & $\begin{array}{l}1 \\
5 \\
4\end{array}$ & $\begin{array}{l}1 \cdot 2 \\
6 \cdot 2 \\
4 \cdot 8\end{array}$ \\
\hline & All Ages & 261 & 245 & 10 & $4 \cdot 1$ \\
\hline \multirow[t]{2}{*}{ Male } & $\begin{array}{l}35-44 \\
45-54 \\
55-64\end{array}$ & $\begin{array}{l}79 \\
92 \\
89\end{array}$ & $\begin{array}{l}71 \\
87 \\
87\end{array}$ & $\begin{array}{r}8 \\
13 \\
13\end{array}$ & $\begin{array}{l}11.3 \\
14.9 \\
14.9\end{array}$ \\
\hline & All Ages & 260 & 245 & 34 & $13 \cdot 5$ \\
\hline
\end{tabular}

(6) Abnormal Haemoglobins

Haemoglobin electrophoresis was carried out ince each survey and the results are given in Table VIII.

Abnormal haemoglobins were found more com- $?$ monly in the rural population $\left(16.8\right.$ per cent.) than $\frac{T}{0}$ in the suburban population $\left(12.4\right.$ per cent.) and $\frac{O}{D}$ 
TABLE VIII

HAEMOGLOBIN ELECTROPHORESIS RESULTS, JAMAICA

\begin{tabular}{|c|c|c|c|c|c|c|c|c|}
\hline \multirow{3}{*}{ Haemoglobin } & \multicolumn{4}{|c|}{ Rural Population } & \multicolumn{4}{|c|}{ Suburban Population } \\
\hline & \multicolumn{2}{|c|}{ Females } & \multicolumn{2}{|c|}{ Males } & \multicolumn{2}{|c|}{ Females } & \multicolumn{2}{|c|}{ Males } \\
\hline & No. & Per cent. & No. & Per cent. & No. & Per cent. & No. & Per cent. \\
\hline $\begin{array}{l}\text { AA } \\
\text { AS } \\
\text { AC } \\
\text { AG } \\
\text { SC } \\
\text { SS }\end{array}$ & $\begin{array}{r}420 \\
67 \\
12 \\
9 \\
1 \\
1\end{array}$ & $\begin{array}{r}82.4 \\
13.1 \\
2.4 \\
1.8 \\
0.2 \\
0.2\end{array}$ & $\begin{array}{r}427 \\
55 \\
11 \\
14 \\
1 \\
0\end{array}$ & $\begin{array}{r}84 \cdot 1 \\
10 \cdot 8 \\
2 \cdot 2 \\
2 \cdot 8 \\
0 \cdot 2 \\
0.0\end{array}$ & $\begin{array}{r}248 \\
31 \\
10 \\
0 \\
0 \\
1\end{array}$ & $\begin{array}{r}85.5 \\
10.7 \\
3.4 \\
0.0 \\
0.0 \\
0.3\end{array}$ & $\begin{array}{r}192 \\
14 \\
6 \\
0 \\
0 \\
0\end{array}$ & $\begin{array}{r}90.6 \\
6.6 \\
2.8 \\
0.0 \\
0.0 \\
0.0\end{array}$ \\
\hline Not Tested & 29 & & 21 & & 6 & & 0 & \\
\hline Total & 539 & & 529 & & 296 & & 212 & \\
\hline
\end{tabular}

were more common in females $(16.5$ per cent.) than in males (14.0 per cent.), but neither of these differences is significant at the 5 per cent. level.

The sickle cell trait was present in 167 subjects (11 per cent.) and sickle cell anaemia was found in two cases. 39 heterozygotes for haemoglobin $\mathrm{C}$ were found (2.6 per cent.); sickle cell-haemoglobin C disease was present in two subjects. 23 heterozygotes for haemoglobin $G$ were found in the rural area but all were probably related.

From the results for the 1,520 subjects tested (haemoglobin electrophoresis results were available for ten people for whom other haematological investigations were not done), an estimate can be made of haemoglobin gene frequencies. These are given in Table IX and were used to calculate the expected frequencies of phenotypes for the combined populations as a whole and for each sub-sample (Table X). The observed distribution of phenotypes for the combined populations did not differ significantly from that expected. The deficiency of subjects with sickle cell disease-two were found where 4.9
TABLE IX

HAEMOGLOBIN GENE FREQUENCIES OBSERVED IN 1,520 JAMAICAN SUBJECTS

\begin{tabular}{c|c|c}
\hline Genes & No. Observed & Relative Frequency \\
\hline A & 2,803 & .9220 \\
S & 173 & .0569 \\
C & 41 & .0135 \\
G & 23 & .0076 \\
\hline Total & 3,040 & 1.0000 \\
\hline
\end{tabular}

were predicted-is presumably due to mortality from this condition in childhood. Such a deficiency of $S$ genes would result in an underestimate of the expected frequency of sickle cell carriers; in fact 167 people with the sickle cell trait were found where $159 \cdot 5$ were predicted. When the sex groups in the two populations were considered separately, the observed distributions of haemoglobin types for the two samples of males differed significantly from the expected values; this was largely attributable to the fourteen heterozygotes for haemoglobin $\mathrm{G}$ from the rural area.

TABLE X

PHENOTYPE FREQUENCIES OBSERVED AND EXPECTED IN EACH POPULATION SAMPLE JAMAICA

\begin{tabular}{|c|c|c|c|c|c|c|c|c|c|c|c|}
\hline \multirow{3}{*}{ Phenotypes } & \multirow{3}{*}{$\begin{array}{l}\text { Frequency } \\
\text { Expected }\end{array}$} & \multirow{2}{*}{\multicolumn{2}{|c|}{ All Subjects }} & \multicolumn{4}{|c|}{ Females } & \multicolumn{4}{|c|}{ Males } \\
\hline & & & & \multicolumn{2}{|c|}{ Rural } & \multicolumn{2}{|c|}{ Suburban } & \multicolumn{2}{|c|}{ Rural* } & \multicolumn{2}{|c|}{ Suburban* } \\
\hline & & Observed & Expected & Observed & Expected & Observed & Expected & Observed & Expected & Observed & Expected \\
\hline $\begin{array}{l}\text { AA } \\
\text { AS } \\
\text { AC } \\
\text { AG } \\
\text { SS } \\
\text { SC } \\
\text { SG } \\
\text { CC } \\
\text { CG } \\
\text { GG }\end{array}$ & $\begin{array}{l}.85016 \\
.10494 \\
.02488 \\
.01396 \\
.00324 \\
.00154 \\
.00086 \\
.00018 \\
.00020 \\
.00006\end{array}$ & $\begin{array}{r}1,287 \\
167 \\
39 \\
23 \\
2 \\
2 \\
0 \\
0 \\
0 \\
0\end{array}$ & $\begin{array}{r}1292 \cdot 2 \\
159 \cdot 5 \\
37 \cdot 8 \\
21 \cdot 2 \\
4 \cdot 9 \\
2 \cdot 3 \\
1 \cdot 3 \\
0 \cdot 3 \\
0 \cdot 3 \\
0 \cdot 1\end{array}$ & $\begin{array}{r}420 \\
67 \\
12 \\
9 \\
1 \\
1 \\
0 \\
0 \\
0 \\
0\end{array}$ & $\begin{array}{r}433 \cdot 6 \\
53 \cdot 5 \\
12 \cdot 7 \\
7 \cdot 1 \\
1 \cdot 7 \\
0.8 \\
0.4 \\
0 \cdot 1 \\
0.1 \\
0.0\end{array}$ & $\begin{array}{r}248 \\
31 \\
10 \\
0 \\
1 \\
0 \\
0 \\
0 \\
0 \\
0\end{array}$ & $\begin{array}{r}246 \cdot 6 \\
30 \cdot 4 \\
7 \cdot 2 \\
4 \cdot 1 \\
0 \cdot 9 \\
0 \cdot 4 \\
0 \cdot 2 \\
0 \cdot 1 \\
0 \cdot 1 \\
0.0\end{array}$ & $\begin{array}{r}427 \\
55 \\
11 \\
14 \\
0 \\
1 \\
0 \\
0 \\
0 \\
0\end{array}$ & $\begin{array}{r}431 \cdot 9 \\
53 \cdot 3 \\
12.6 \\
7.1 \\
1.7 \\
0.8 \\
0.4 \\
0.1 \\
0.1 \\
0.0\end{array}$ & $\begin{array}{r}192 \\
14 \\
6 \\
0 \\
0 \\
0 \\
0 \\
0 \\
0 \\
0\end{array}$ & $\begin{array}{r}180 \cdot 2 \\
22 \cdot 3 \\
5 \cdot 3 \\
3 \cdot 0 \\
0 \cdot 7 \\
0 \cdot 3 \\
0 \cdot 2 \\
0 \cdot 0 \\
0 \cdot 0 \\
0 \cdot 0\end{array}$ \\
\hline Total & $1 \cdot 00002$ & 1,520 & $1519 \cdot 9$ & 510 & $510 \cdot 0$ & 290 & $290 \cdot 0$ & 508 & $508 \cdot 0$ & 212 & $212 \cdot 0$ \\
\hline
\end{tabular}

* Distributions of phenotypes differ from expected; $P<\cdot 05$. 
The gene for $\beta$-thalassaemia associated with elevated $\mathrm{HbA}_{2}$ levels is not uncommon in Jamaicans. Such people have slightly hypochromic red cells and the MCHC may be as low as 30 per cent. in the presence of normal serum iron and saturation levels. $\mathrm{HbA}_{2}$ levels were not measured in this survey but, from the appearance of the blood films and paper electrophoresis strips, the prevalence of $\beta$-thalassaemia is in the order of 0.8 per cent.

\section{Discussion}

The prevalence of anaemia in these rural and suburban Jamaican population samples is, perhaps, surprisingly low in view of the poor living conditions and shortage of animal protein. The distributions of haemoglobin levels are shifted towards lower values in both sexes compared with those in Wales (Fig. 1) but the average rates of clinically significant anaemia in rural and suburban women $(9 \cdot 5$ and 9.6 per cent.) were of the same order as those found in the United Kingdom $(6 \cdot 3$ and $11 \cdot 5$ per cent.).

Most of the cases of anaemia found were hypochromic, and it is difficult in such surveys to estimate the importance of the various possible causes. In women, iron-deficiency anaemia is usually associated with losses due to menstruation and childbearing, and the higher prevalence of uterine fibroids in Negro women (Torpin, Pund, and Peeples, 1942), and the larger families borne by Jamaican than United Kingdom women, might have been expected to cause considerably more anaemia. However, the finding that nearly 10 per cent. of women had haemoglobin levels less than $11 \mathrm{~g} . / 100 \mathrm{ml}$. suggests that the introduction of supplementary iron into some staple diet item, such as bread, might be of benefit.

The men in the Jamaican rural population showed a considerably higher average rate of anaemia (less $\infty$ than $12 \mathrm{~g}$. $\mathrm{Hb} / 100 \mathrm{ml} .: 11.9$ per cent.) than in the suburban population where it was $4 \cdot 1$ per cent. $\frac{3}{8}$ Comparable figures for the United Kingdom were ? 4.6 and 1.7 per cent. respectively. In over 50 per $\vec{F}$ cent. of cases the anaemia was hypochromic with $\stackrel{0}{+}$ MCHC values below 31 per cent., and iron deficiency was confirmed in those cases where serum iron and saturation of transferrin was measured.

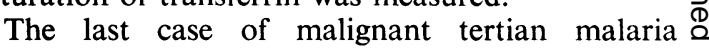
(Plasmodium falciparum) contracted in Jamaica was diagnosed in 1961. Since then there have been only a $\vec{\circ}$

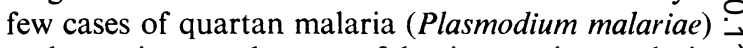
and two imported cases of benign tertian malaria $\vec{\omega}$ (Plasmodium vivax). Eradication of the disease in $\stackrel{\Omega}{\rightarrow}$ Jamaica was registered by PAHO/WHO in 1965, and this cause of anaemia can be discounted. Hookworm, probably mostly Necator americanus $\vec{i}$ rather than Ankylostoma duodenale, is common in rural Jamaica and was found in 30.7 per cent. of $\stackrel{c}{ }$ men and $12 \cdot 7$ per cent. of women in the first survey at Lawrence Tavern. (Intestinal parasites were not $\vec{\longrightarrow}$ investigated in the other surveys). Though the $\frac{D}{0}$ intestinal loads were thought to be light, haemoglobin values were generally slightly lower in subjects $\vec{\bullet}$ infested with hookworm than in those withou (Table XI), the mean difference being about 0.4 . Men walk unshod more frequently than do womeq. in rural areas of the island, which probably accounts for the sex difference in the prevalence of hookworm infestation, and men in rural areas wear shoes less than do those in the suburbs, and therefore probably suffer more from hookworm.

Hookworm infestation may account for some of the findings, but 40 per cent. of the anaemic subjects in the rural area were not cases of hypochromic anaemia, and the differences between the mean haemoglobin levels in rural and suburban Jamaicans, and between rural Jamaicans and men in the United

TABLE XI

MEAN HAEMOGLOBIN VALUES IN SUBJECTS WITH AND WITHOUT HOOKWORM INFESTATION LAWRENCE TAVERN, JAMAICA

\begin{tabular}{|c|c|c|c|c|c|}
\hline \multicolumn{2}{|c|}{ Population Samples } & \multicolumn{4}{|c|}{ Results of Examination of Stools } \\
\hline \multirow{2}{*}{ Sex } & \multirow{2}{*}{ Age (yrs) } & \multicolumn{2}{|c|}{ Hookworm Found } & \multicolumn{2}{|c|}{ Hookworm not Found } \\
\hline & & No. & $\mathrm{Hb} \mathrm{g.} / 100 \mathrm{ml}$. & No. & $\mathrm{Hb} \mathrm{g./} / 100 \mathrm{ml}$. \\
\hline \multirow[t]{2}{*}{ Female } & $\begin{array}{l}35-44 \\
45-54 \\
55-64\end{array}$ & $\begin{array}{r}5 \\
12 \\
15\end{array}$ & $\begin{array}{l}12 \cdot 6 \\
12 \cdot 2 \\
11 \cdot 9\end{array}$ & $\begin{array}{l}82 \\
75 \\
71\end{array}$ & $\begin{array}{l}12 \cdot 2 \\
12 \cdot 6 \\
12 \cdot 7\end{array}$ \\
\hline & All Ages & 32 & $12 \cdot 1$ & 228 & $12 \cdot 5$ \\
\hline \multirow[t]{2}{*}{ Male } & $\begin{array}{l}35-44 \\
45-54 \\
55-64\end{array}$ & $\begin{array}{l}27 \\
27 \\
23\end{array}$ & $\begin{array}{l}13 \cdot 8 \\
13 \cdot 3 \\
12 \cdot 8\end{array}$ & $\begin{array}{l}56 \\
57 \\
61\end{array}$ & $\begin{array}{l}14 \cdot 0 \\
13 \cdot 6 \\
13 \cdot 4\end{array}$ \\
\hline & All Ages & 77 & $13 \cdot 3$ & 174 & $13 \cdot 7$ \\
\hline
\end{tabular}


Kingdom samples, are not accompanied by comparable differences in $\mathrm{MCHC}$, suggesting that some factor other than iron-deficiency may be involved.

Dietary surveys were carried out in Lawrence Tavern and in Hermitage (a suburb which is socioeconomically similar to August Town and adjoins it) in 1960 (Cruickshank and Fox, 1961). In these surveys the food consumed at all meals by members of representative households was weighed and recorded every day during one week. The findings for adults aged 20 to 50 years show marked differences, particularly in the intake of animal proteins and fats, between the two populations (Table XII). The requirements of nutrients for people aged 45 which are recommended by the National Research Council, Washington (1953) are also shown in Table XII, and indicate that the diets in Lawrence Tavern fall below the recommended levels in many items, particularly in protein intake. Dietary iron was higher in the suburban than in the rural area; intake was lower than recommended for women, but men in both areas had an adequate intake. No allowance was made for iron intake derived from cooking pots in these surveys. Anthropometric measurements from the surveys (Table XIII) provide additional evidence that the rural population is probably less well nourished. However, the daily energy expenditure in Lawrence Tavern, with its steep tracks, must be considerably higher than in the low-lying and comparatively flat terrain at August Town, and this presumably accentuates the effect on weight of the poorer diet.

The details of the cases of anaemia show that a considerable proportion of them had symptoms which may be related. Mild angina was particularly common in Lawrence Tavern and more commonly found in the anaemic; a high frequency of symptoms suggestive of peptic ulceration was also found.

Glucose-6-phosphate dehydrogenase deficiency, which is known to be a sex-linked inherited characteristic, shows considerable variability between different population groups. Its prevalence in Negroes is much higher than in whites, and Motulsky (1960) has given evidence that it exists as a genetic polymorphism; Allison and Clyde (1961), and Siniscalco, Bernini, Latte, and Motulsky (1961) have

TABLE XII

RESULTS OF DIETARY SURVEY (1960).

PERSONS AGED 20 TO 25 YRS, LAWRENCE TAVERN AND HERMITAGE, JAMAICA

\begin{tabular}{|c|c|c|c|c|c|c|c|c|c|c|c|c|}
\hline \multirow{3}{*}{ Sex } & \multirow{3}{*}{ Area } & \multirow{3}{*}{$\begin{array}{c}\text { No. } \\
\text { Investi- } \\
\text { gated }\end{array}$} & \multirow{3}{*}{$\begin{array}{l}\text { Mean } \\
\text { Caloric } \\
\text { Intake }\end{array}$} & \multicolumn{2}{|c|}{ Protein } & \multicolumn{2}{|c|}{ Fat } & \multirow[b]{2}{*}{$\begin{array}{l}\text { Carbo- } \\
\text { hydrate }\end{array}$} & \multirow[b]{2}{*}{ Iron } & \multirow[b]{2}{*}{$\begin{array}{l}\text { Thia- } \\
\text { mine }\end{array}$} & \multirow[b]{2}{*}{$\begin{array}{l}\text { Ribo- } \\
\text { flavine }\end{array}$} & \multirow[b]{2}{*}{ Niacin } \\
\hline & & & & Animal & $\begin{array}{l}\text { Vege- } \\
\text { table }\end{array}$ & Animal & $\begin{array}{l}\text { Vege- } \\
\text { table }\end{array}$ & & & & & \\
\hline & & & & (g.) & (g.) & (g.) & (g.) & (g.) & (mg.) & (mg.) & (mg.) & (mg.) \\
\hline Female & $\begin{array}{l}\text { Lawrence } \\
\text { Tavern } \\
\text { Hermitage }\end{array}$ & $\begin{array}{l}57 \\
37\end{array}$ & $\begin{array}{l}1,559 \\
1,978\end{array}$ & $\begin{array}{l}16 \cdot 2 \\
27 \cdot 9\end{array}$ & $\begin{array}{l}24 \cdot 4 \\
30 \cdot 0\end{array}$ & $\begin{array}{l}10 \cdot 5 \\
30 \cdot 6\end{array}$ & $\begin{array}{l}12 \cdot 9 \\
33 \cdot 8\end{array}$ & $\begin{array}{l}281 \cdot 9 \\
296 \cdot 4\end{array}$ & $\begin{array}{r}9 \cdot 8 \\
11 \cdot 6\end{array}$ & $\begin{array}{l}0 \cdot 8 \\
1 \cdot 2\end{array}$ & $\begin{array}{l}0 \cdot 6 \\
1 \cdot 2\end{array}$ & $\begin{array}{r}8 \cdot 4 \\
12 \cdot 8\end{array}$ \\
\hline Male & $\begin{array}{l}\text { Lawrence } \\
\text { Tavern } \\
\text { Hermitage }\end{array}$ & $\begin{array}{l}66 \\
33\end{array}$ & $\begin{array}{l}2,237 \\
2,584\end{array}$ & $\begin{array}{l}21 \cdot 9 \\
37 \cdot 6\end{array}$ & $\begin{array}{l}35 \cdot 1 \\
37 \cdot 1\end{array}$ & $\begin{array}{l}16 \cdot 2 \\
35 \cdot 4\end{array}$ & $\begin{array}{l}15 \cdot 1 \\
43 \cdot 8\end{array}$ & $\begin{array}{l}408 \cdot 6 \\
383 \cdot 8\end{array}$ & $\begin{array}{l}13 \cdot 5 \\
15 \cdot 5\end{array}$ & $\begin{array}{l}1 \cdot 1 \\
1 \cdot 4\end{array}$ & $\begin{array}{l}0.7 \\
1 \cdot 5\end{array}$ & $\begin{array}{l}10 \cdot 8 \\
17 \cdot 4\end{array}$ \\
\hline $\begin{array}{l}\text { Recom- } \\
\text { mended }\end{array}$ & Females & & 2,100 & \multicolumn{2}{|c|}{$55+$} & & & & 12 & $1 \cdot 1$ & $1 \cdot 4$ & 11 \\
\hline $\begin{array}{l}\text { Persons } \\
\text { aged } 45 \text { yrs }\end{array}$ & Males & & 2,900 & \multicolumn{2}{|c|}{$65+$} & & & & 12 & $1 \cdot 5$ & $1 \cdot 6$ & 15 \\
\hline
\end{tabular}

* National Research Council Food and Nutrition Board recommended daily dietary allowances.

† Assuming biological value is 75 and that two-thirds of total protein is from animal source (Cruickshank and Fox, 1961).

TABLE XIII

MEAN HEIGHTS AND WEIGHTS IN LAWRENCE TAVERN AND AUGUST TOWN, JAMAICA

\begin{tabular}{|c|c|c|c|c|c|c|c|c|c|c|c|}
\hline \multicolumn{2}{|c|}{ Population Sample .. } & \multicolumn{5}{|c|}{ Rural } & \multicolumn{5}{|c|}{ Suburban } \\
\hline \multirow{2}{*}{ Sex } & \multirow{2}{*}{ Age (yrs) } & \multirow[b]{2}{*}{ No. } & \multicolumn{2}{|c|}{ Height (in.) } & \multicolumn{2}{|c|}{ Weight (lb.) } & \multirow[b]{2}{*}{ No. } & \multicolumn{2}{|c|}{ Height (in.) } & \multicolumn{2}{|c|}{ Weight (lb.) } \\
\hline & & & Mean & S.D. & Mean & S.D. & & Mean & S.D. & Mean & S.D. \\
\hline Female & $\begin{array}{l}35-44 \\
45-54 \\
55-64\end{array}$ & $\begin{array}{l}179 \\
180 \\
177 \\
\end{array}$ & $\begin{array}{l}62 \cdot 2 \\
61 \cdot 7 \\
61 \cdot 1 \\
\end{array}$ & $\begin{array}{l}2 \cdot 4 \\
2 \cdot 2 \\
2 \cdot 2\end{array}$ & $\begin{array}{l}134 \cdot 1 \\
129 \cdot 5 \\
123 \cdot 8\end{array}$ & $\begin{array}{l}25 \cdot 0 \\
29 \cdot 3 \\
22 \cdot 8 \\
\end{array}$ & $\begin{array}{r}122 \\
99 \\
73\end{array}$ & $\begin{array}{l}62 \cdot 7 \\
62 \cdot 2 \\
61 \cdot 5\end{array}$ & $\begin{array}{l}2 \cdot 6 \\
2 \cdot 5 \\
2 \cdot 4\end{array}$ & $\begin{array}{l}140 \cdot 6 \\
145 \cdot 4 \\
135 \cdot 6\end{array}$ & $\begin{array}{l}34 \cdot 0 \\
30 \cdot 2 \\
29 \cdot 8\end{array}$ \\
\hline Male & $\begin{array}{l}35-44 \\
45-54 \\
55-64\end{array}$ & $\begin{array}{l}169 \\
181 \\
177\end{array}$ & $\begin{array}{l}65 \cdot 5 \\
65 \cdot 7 \\
65 \cdot 2\end{array}$ & $\begin{array}{l}3 \cdot 0 \\
2 \cdot 2 \\
2 \cdot 3\end{array}$ & $\begin{array}{l}138 \cdot 6 \\
137 \cdot 9 \\
132 \cdot 8\end{array}$ & $\begin{array}{l}16 \cdot 3 \\
16 \cdot 8 \\
18 \cdot 7\end{array}$ & $\begin{array}{l}92 \\
75 \\
39\end{array}$ & $\begin{array}{l}66 \cdot 8 \\
66 \cdot 3 \\
66 \cdot 0\end{array}$ & $\begin{array}{l}2 \cdot 4 \\
2 \cdot 5 \\
2 \cdot 9\end{array}$ & $\begin{array}{l}147 \cdot 7 \\
144 \cdot 2 \\
142 \cdot 7\end{array}$ & $\begin{array}{l}19 \cdot 0 \\
22 \cdot 3 \\
25 \cdot 6\end{array}$ \\
\hline
\end{tabular}


suggested that G-6-PD deficient people may be resistant to falciparum malaria though Porter, Boyer, Watson-Williams, Adams, Szeinberg, and Siniscalco (1964) believe that other selective factors are maintaining the G-6-PD polymorphism. G-6-PD deficiency has been demonstrated in 13 per cent. of United States Negroes (Childs, Zinkham, Browne, Kimbro, and Torbert, 1958); in Nigeria, Harris and Gilles (1961) found it in about 20 per cent. of males, and Capps, Gilles, Jolly, and Worlledge (1963), studying newborn infants in Nigeria, found the enzyme to be deficient in 20.6 per cent. of male and 10.7 per cent. of female infants. Our figures for Jamaican rural adults were 13.5 per cent. in males and $4 \cdot 1$ per cent. in females. The lower values in United States and Jamaican Negro subjects may be due to their more heterogeneous racial characteristics. The great majority of Jamaicans have African ancestry but in many it is mixed with Caucasian, Indian, or Chinese stock.

The frequencies of the 3,040 genes in this general population sample probably give the most reliable picture of haemoglobin genes available for West Indians, but the high incidence of haemoglobin $G$ found in Lawrence Tavern is almost certainly atypical.

The haematological picture in Jamaica is an interesting but complicated one. It is complicated by its people being of various ethnic origins, by dietary factors, by intestinal parasites, by a variety of causes of blood loss, and by a high prevalence of haemoglobinopathies. The haemoglobin levels are, however, close to those of British populations, especially for women, despite the considerable differences in standards of living.

\section{SUMmary}

Haematological investigations have been carried out in Jamaican population samples of about 1,000 adults aged 35 to 64 years in an inland rural area, and about 500 adults of the same age in a suburban district. These formed 85 per cent. of random samples chosen from each area.

The mean haemoglobin levels of women in the two areas were similar and only slightly lower than those reported in recent surveys in the United Kingdom. Men in the rural area had lower mean haemoglobin levels than in the suburban area and their mean values were more than $1 \mathrm{~g} . / 100 \mathrm{ml}$. lower than those in United Kingdom urban populations. Much of the anaemia detected was hypochromic and confirmed by low serum iron measurements, and hookworm is probably an important contributing factor in rural men, but as the difference in haemoglobin levels between men in the rural and suburban populations and in the United Kingdom were not accompanied by comparable differences in $\mathrm{MCHC}$, factors other than irondeficiency may contribute to them.

Haemoglobin electrophoresis was carried out on 1,520 blood specimens and gene frequencies for haemoglobins, A, S, C, and G (Accra) have been calculated. Glucose-6-phosphate dehydrogenase deficiency was detected in 13.5 per cent. of men and $4 \cdot 1$ per cent. of women in the rural area.

We are grateful to the many people in Lawrence Tavern and in August Town who so willingly cooperated in these surveys, and wish to record our thanks for the help of colleagues in the department of Haematology, University of the West Indies, and in the M.R.C. Epidemiological Research Unit. Dr J. Parker-Williams carried out the glucose-6-phosphate dehydrogenase deficiency tests. We are grateful to Dr P. C. Elwood and Dr G. S. Kilpatrick for allowing us to examine and use their data and to $\mathrm{Dr} \mathrm{H}$. Lehmann for identifying the haemoglobin G (Accra).

\section{REFERENCES}

Allison, A. C., and Clyde, D. F. (1961). Brit. med. J., $1,1346$.

Beale, R. N., Bostrom, J. O., and Taylor, R. F. (1961). J. clin. Path., 14, 488.

$$
\text { (1962). Ibid., 15, } 156 .
$$

Bainton, D. F., and Finch, C. A. (1964). Amer. J. Med., 37, 62 .

Capps, F. P. A., Gilles, H. M., Jolly, H., and Worlledge, S. M. (1963). Lancet, 2, 379.

Childs, B., Zinkham, W., Browne, E. A., Kimbro, E. L., and Torbert, J. V. (1958). Bull. Johns Hopk. Hosp., 102, 21.

Cruickshank, E. K., and Fox, H. (1961) "Report to Scientific Research Council, Jamaica" (unpublished).

Elwood, P. C. (1964). Brit. J. prev. Soc. Med., 18, 81.

Gibbs, W. N. (1963). W. Indian med. J., 12, 103.

Goldberg, C. A. J. (1959). Clin. Chem., 5, 446.

Hamilton, L. D., Gubler, C. J., Cartwright, G. E., and Wintrobe, M. M. (1950). Proc. Soc. exp. Biol. (N.Y.), $75,65$.

Harris, R., and Gilles, H. M. (1961). Ann. hum. Genet., 25, 199.

Jordan, A. (1956). Association of Clinical Pathologists: Broadsheet, No. 14.

Kilpatrick, G. S. (1961). Brit. med. J., 2, 1736.

__ and Hardisty, R. M. (1961). Ibid., 1, 778. 
Lehmann, H., Beale, D., and Bio-Doku, F. S. (1964). Nature (Lond.), 203, 363.

and Smith, E. B. (1954). Trans. roy. Soc. trop. Med. Hyg., 48, 12.

Milner, P. F. (1965). Unpublished.

Motulsky, A. G. (1960). Hum. Biol. 32, 28.

— and Campbell-Kraut, J. M. (1961). In "Proceedings of the Conference on Genetic Polymorphisms and Geographic Variations in Disease, 1960", ed. B. S. Blumberg, p. 159. Grune and Stratton, New York.
National Research Council, Washington (1953). "Recommended Dietary Allowances” (revised), (Publ. 302). Washington D.C.

Porter, I. H., Boyer, S. H., Watson-Williams, E. J., Adam, A., Szeinberg, A., and Siniscalco, M. (1964). Lancet, 1, 895.

Siniscalco, M., Bernini, L., Latte, B., and Motulsky, A. G. (1961). Nature (Lond.), 190, 1179.

Torpin, R., Pund, E., and Peeples, W. J. (1942). Amer. J. Obstet. Gynec., 44, 569.

Wood, M. M., and Elwood, P. C. (1966). Brit. J. prev. soc. Med., 20, 117. 